\title{
Opening Moves - Drivers, Enablers and Barriers of Open Data in a Semi-public Organization
}

\author{
Anne Fleur van Veenstra and Tijs A. van den Broek \\ TNO, Brassersplein 2, 2612 CT Delft, The Netherlands \\ \{annefleur.vanveenstra, tijs.vandenbroek\} atno.nl
}

\begin{abstract}
Governments around the world are opening up their data to increase transparency and stimulate re-use of their data. Semi-public organizations follow, but often for different purposes as they also aim to realize commercial gains with their data. Many organizations, however, find the process of opening up data cumbersome as changes need to be made to different organizational layers. This paper identifies drivers, enablers, and barriers of open data, by reviewing literature and by conducting a case study of open data in a semipublic organization in the Netherlands. We found that while the drivers for opening up data remain the same in every phase of the process, the enablers and barriers shift between the different phases. While in the beginning of the process, organizational factors such as having an implementation strategy and ensuring data quality gained much attention, this attention shifted to factors related to re-use of data. Further research should thus focus on how to develop valuable open data business models, how to foster re-use and build strategic partnerships with users.
\end{abstract}

Keywords: Open Data, Open Government, Drivers, Enablers, Barriers.

\section{Introduction}

Since President Obama of the United States announced his strategy for 'open government' on his first day in office [1], government organizations around the world began opening up their data. The main goals of open data for these organizations are to become more transparent and accountable to citizens [2] and to realize economic activity by stimulating re-use [3]. By now, also semi-public organizations, such as cultural heritage foundations, public transport organizations and research institutes, have jumped on the bandwagon. Although these organizations also see the benefits of transparency and re-use, their purpose of opening up data extends to enhance the value of their data for their own (commercial) purposes. They, for example, aim to commercially exploit their data or forge strategic partnerships with app developers.

While strong drivers are present spurring open data developments, many public and semi-public organizations find the process of opening up data cumbersome [4]. Many challenges remain as changes need to be made to different organizational aspects [5]. This paper investigates the process of opening up data to find out which drivers, enablers and barriers exist in organizations that open up their data to the 
public. By investigating a case study of a research and technology organization (RTO) in the Netherlands, this paper looks at which factors influence the process of opening up data. This paper uses a two-pronged approach. First, based on literature, we develop a framework for identification of enablers and challenges to open data. Then, using longitudinal case study research, we identify the main drivers, enablers and barriers within the RTO. When organizations have better insight in this process, they are more likely to successfully open up their data.

The next section identifies drivers, enablers and barriers of open government and open data from literature and subsequently presents an overview that can be used for the identification of factors influencing the process of opening up data. In the third section, we present the case study methodology, followed by the case study of the RTO in the fourth section. The fifth section presents and discusses the main findings from the case study. Finally, the sixth section formulates conclusions and recommendations for further research.

\section{Drivers, Enablers and Barriers of Open Data}

Information technologies, such as the semantic web and social media, have increased the ability to collaboratively produce, share, distribute and innovate [3]. These technologies gave rise to openness as an organizational strategy: open innovation, open source, open standards, open web platforms and, predominantly in the public sector, open government and open data. Currently, an increasing number of government agencies around the world is publishing public sector information (PSI) such as weather forecasts, legal documents, crime statistics, geospatial data, traffic data and educational data [6-8]. While PSI is traditionally published in a humanreadable or proprietary format on the internet (e.g. PDF or HTML) [7,8], open data requires a machine-readable format (e.g. CSV, XML or RDF) and a minimum of juridical, economical and technical barriers to re-use the data for social or commercial purposes $[9,10]$. After open data strategies were put in place at the national level, the revision of the European PSI directive is currently pushing the open data movement [11]. An extension of open data is linked data: the semantics of the data are modelled and the data can be linked to and from external data sets $[12,13]$.

Government agencies generally have three driving forces to open up their data: transparency, innovation and efficiency [6,14,15]. Firstly, open data is seen as an instrument to increase transparency and accountability [2,14], e.g. by facilitating the Freedom of Information act $[15,16]$. Predominantly in the US and the UK, citizens and NGOs push for open data to increase their ability to evaluate the process and performance of government agencies [3]. Secondly, open data is seen as an instrument to foster innovation [3]. The European Commission claims that a European open data strategy can lead to a yearly economic value of 70-140 billion euros in the European Union alone. The promise of open data is that re-use of PSI by private and public parties will grow, resulting in new commercial and public services $[11,17]$. Thirdly, open data is seen as a way to make information exchange within and outside the government agency more efficient [14]. 
The process of opening up data, however, is perceived as cumbersome and many challenges remain [4]. One reason is that opening up data is often presented too simplistically [4], while, in reality, developing an open data strategy requires organizational transformation [5], with changes taking place on multiple levels. Research on public sector change and the implementation of information systems in (government) organizations often looks at drivers and enablers to identify those aspects that need to be in place to realize this change $[18,19]$. Furthermore, also the identification of barriers is found important to deal with them in undertaking transformational efforts [20]. Drivers, enablers and barriers are - while not the same related to each other and, therefore, we categorize these factors into four groups used in research or organizational change: information technology, organizational and managerial, legal and regulatory, and institutional and environmental [21]. For every category we reviewed literature to identify the factors that influence the process of opening up data. An overview of these factors is shown in table 1.

Table 1. Overview of organizational drivers, enablers and barriers to open data

\begin{tabular}{|c|c|c|c|}
\hline & Drivers & Enablers & Barriers \\
\hline $\begin{array}{l}\text { Information } \\
\text { technology }\end{array}$ & Linked data $[4,12,13]$ & $\begin{array}{l}\text { Usefulness of the } \\
\text { databases }[4,10]\end{array}$ & $\begin{array}{l}\text { Poor data structures } \\
{[4,22] ; \text { Legacy systems }} \\
{[4,22] \text {; Fragmented }} \\
\text { databases }[4,22] ; \text { Limited } \\
\text { data quality }[4,6] ; \text { Lack } \\
\text { of standardization }[4,6]\end{array}$ \\
\hline $\begin{array}{l}\text { Organizational } \\
\text { and managerial } \\
\text { Legal and } \\
\text { regulatory }\end{array}$ & $\begin{array}{l}\text { Efficiency and } \\
\text { budget cuts }[4,6,14] \\
\text { PSI directive [9]; } \\
\text { Law enforcement [6] }\end{array}$ & $\begin{array}{l}\text { Data stewardship } \\
{[4,10]}\end{array}$ & $\begin{array}{l}\text { Complexity of the } \\
\text { changes to be made }[4,5] \\
\text { Privacy and data } \\
\text { protection }[4,6] ; \\
\text { classified information } \\
{[4,6]}\end{array}$ \\
\hline $\begin{array}{l}\text { Institutional and } \\
\text { environmental }\end{array}$ & $\begin{array}{l}\text { Transparency and } \\
\text { accountability } \\
{[2,4,14] \text {; Enabling re- }} \\
\text { use }[3,4,11,17]\end{array}$ & $\begin{array}{l}\text { Political } \\
\text { leadership [6]; } \\
\text { Value for users } \\
{[4,11]}\end{array}$ & $\begin{array}{l}\text { Closed culture of } \\
\text { government [6]; Lack of } \\
\text { support of user feedback } \\
\text { [4] }\end{array}$ \\
\hline
\end{tabular}

The drivers of the process of opening up data are linking data on the information technology layer, efficiency on the organizational layer, compliance on the legal and regulatory layer, and transparency, accountability, and enabling re-use and innovation on the institutional and environmental layer. The enablers found in literature are the usefulness of databases, including easier access to data on the information technology layer, data stewardship and management on the organizational and managerial layer, and political leadership and value for users (including economic as well as societal value) on the institutional and environmental layer. The barriers on the information technology layer are poor data structures, legacy systems, fragmented databases, limited data quality, and lack of standardization. On the organizational and managerial layer the barrier found is the complexity of the changes to be made. On the legal and regulatory layer we identified privacy, data protection, and classified 
information as barriers, and on the institutional and environmental layer the closed culture of government and the lack of support of user feedback were found. We will use the case study to validate and elaborate these drivers, enablers and barriers.

\section{Case Study Methodology}

In the previous section, we used literature to identify drivers, enablers and barriers to opening data in an organization. The second step of this research is to identify the factors influencing the process of opening up data in practice to validate, refine and/or elaborate the findings from literature. For investigating the process of opening data we use an interpretivist methodology for in-depth research, which fits the complexity of the matter [23]. Using a longitudinal case study approach we aim to identify the drivers, enablers and barriers to opening data. The case selected is TNO, an RTO based in the Netherlands. As this semi-public organization is in the middle of opening up its data to the public, we were able to collect data throughout the process.

For the data collection we used a triangulation of methods [24]: action research, surveys and interviews with relevant stakeholders. Firstly, we were involved in the process of opening up data, supporting the relevant stakeholders during the process. Secondly, a survey was sent out twice to different stakeholders of open data within the organization (such as data owners, senior management, information officers, strategists and lawyers). These surveys aimed to capture the attitude of stakeholders with regard to the importance of open data for the RTO to identify the drivers, enablers and barriers within the organization. These surveys were sent out at different moments in time: the first survey was sent before the process of opening data commenced in September 2012 and the second survey was sent out in November 2012 after the first data sets had been opened up.

Three main questions were asked in the survey. The first question concerned the reasons (drivers) for opening up data and for implementing an open data strategy. The second question concerned the enablers of opening up the data. And the third question concerned the barriers and impediments to opening data. Options for answering the questions were provided and the respondents were asked to indicate the importance of the different options on a five-point scale ranging from very important to very unimportant. The second survey was an evolution of the first. While the main questions remained the same, some answers were added based on new insights. The response rate for both surveys approximated 50\% (14 and 15 responses out of approximately 30 invitations, respectively). The second survey showed that most respondents considered themselves data owners, collectors, analysts or having a commercial role. Technology developers, legal and communication professionals were relatively underrepresented.

To validate the survey findings, we conducted nine semi-structured interviews with different types of stakeholders. These interviews were undertaken in November 2012 and in January 2013 and lasted around 45 minutes. These interviews were held with a five data owners, a director or research, a strategist and an information manager to reflect on the process of opening up their data. Central questions concerned the strategic choices for opening up data of the RTO, and their experiences with opening data, such as the main driving, enabling and impeding factors. 


\section{Case Study: RTO}

The RTO has a history in opening up data. The organization has long opened some of its research data to the public; for some time, the organization even was the largest contributor of datasets to the national open data portal data.overheid.nl. However, opening up data never took place in a structured manner; occasionally, datasets were opened. Therefore, during the fall of 2012 and beginning of 2013 the RTO undertook a pilot project to investigate the process of opening up data with the purpose of learning from this process. In this pilot project three datasets from different domains (transportation, working conditions, and geology) were opened up. The datasets took part in a hackathon, a workshop in which programmers can re-use the data to develop their own services. The first survey was sent to the relevant stakeholders during the preparation of the databases for the hackathon, and the second survey was sent during the publication phase. Afterwards, we evaluated the process during the interviews.

\subsection{Open Data Strategies}

The RTO is a semi-public organization and, as such, the organization is accountable to the Freedom of Information act. Furthermore, the central government has demanded the RTO to open up all research results and data that are not harmful to the privacy of individuals nor to the security of society. In addition, the RTO aims to adopt a strategy of enabling others to use data that are gathered using public funds. At the same time, as the organization competes on the European as well on the national market for research projects on a daily basis, the RTO aims to develop a business model using its data to attract new research projects. It aims to do so either by creating new business models for existing datasets, or by helping other organizations to develop an open data strategy. The organization is thus in need of an open data strategy that supports these different objectives.

In the surveys and the interviews, we asked questions about the relevance for the RTO of having an open data strategy in place. In the surveys, the respondents were asked what they consider to be the importance of a number of drivers for opening up data, based on a five-point scale ranging from very important to very unimportant. Based on the answers in the first survey, the second survey was somewhat altered. The main difference between the two surveys is that we added drivers that are related to the commercial proposition of open data. The drivers that were included in the surveys and in the interviews, as well as their results, can be found in table 2 .

Table 2. Drivers of open data in the RTO

\begin{tabular}{llll}
\hline Open data drivers & $\begin{array}{l}\text { Preparation } \\
\text { phase survey }\end{array}$ & $\begin{array}{l}\text { Publication phase } \\
\text { survey }\end{array}$ & $\begin{array}{l}\text { Evaluation phase } \\
\text { interviews }\end{array}$ \\
\hline $\begin{array}{l}\text { Open data should be } \\
\text { part of the mission } \\
\text { of the RTO }\end{array}$ & $\begin{array}{l}11 \text { out of } 14 \\
\text { respondents } \\
\text { consider this } \\
\text { important }\end{array}$ & $\begin{array}{l}10 \text { out of } 15 \\
\text { respondents consider } \\
\text { this important }\end{array}$ & $\begin{array}{l}\text { All interviewees } \\
\text { consider this the most } \\
\text { important reason for } \\
\text { opening data }\end{array}$ \\
\hline
\end{tabular}


Table 2. (Continued.)

\begin{tabular}{|c|c|c|c|}
\hline $\begin{array}{l}\text { Using open data as } \\
\text { a sales instrument } \\
\text { and developing } \\
\text { business models for } \\
\text { open data }\end{array}$ & $\begin{array}{l}\text { Not included in the } \\
\text { survey }\end{array}$ & $\begin{array}{l}\text { Considered important } \\
\text { by } 9 \text { and } 7 \text { of the } 15 \\
\text { respondents } \\
\text { respectively }\end{array}$ & $\begin{array}{l}\text { Interviewees indicate } \\
\text { its importance, but } \\
\text { find it difficult to } \\
\text { develop business } \\
\text { models }\end{array}$ \\
\hline $\begin{array}{l}\text { Re-use of open data } \\
\text { by third parties }\end{array}$ & $\begin{array}{l}8 \text { out of } 14 \\
\text { respondents found } \\
\text { this strategy } \\
\text { important }\end{array}$ & $\begin{array}{l}\text { Found important by } 7 \\
\text { of the } 15 \text { respondents }\end{array}$ & $\begin{array}{l}\text { Considered } \\
\text { important, but also a } \\
\text { threat, as others can } \\
\text { freely re-use data } \\
\text { collected by the RTO }\end{array}$ \\
\hline $\begin{array}{l}\text { Facilitating data } \\
\text { sharing within the } \\
\text { organization }\end{array}$ & $\begin{array}{l}7 \text { out of } 14 \\
\text { respondents } \\
\text { indicated its } \\
\text { importance }\end{array}$ & $\begin{array}{l}\text { Only } 5 \text { out of the } 15 \\
\text { respondents } \\
\text { considered this } \\
\text { important }\end{array}$ & \\
\hline $\begin{array}{l}\text { Gaining insight into } \\
\text { how the } \\
\text { organization works }\end{array}$ & $\begin{array}{l}\text { Only } 5 \text { out of } 14 \\
\text { respondents found } \\
\text { this important }\end{array}$ & $\begin{array}{l}\text { Was left out of the } \\
\text { second survey }\end{array}$ & \\
\hline
\end{tabular}

\subsection{Enablers of Open Data}

In both surveys and in the interviews, we asked questions on the enablers the RTO envisaged for opening up the data. Hence, we asked the respondents and interviewees to indicate which enablers would be most important in each phase. Using a five-point scale (ranging from very important to very unimportant) we asked the respondents to indicate how they value the enablers. Based on the insights gained from the first survey, the second survey was changed somewhat. The main differences between the surveys are the addition of business-related indicators, and the introduction of risks such as privacy violation and reputation damage. The results from the surveys and the interviews can be found in table 3 .

Table 3. Enablers of open data in the RTO

\begin{tabular}{|c|c|c|c|}
\hline $\begin{array}{l}\text { Open data } \\
\text { enablers }\end{array}$ & $\begin{array}{l}\text { Preparation phase } \\
\text { survey }\end{array}$ & $\begin{array}{l}\text { Publication phase } \\
\text { survey }\end{array}$ & $\begin{array}{l}\text { Evaluation phase } \\
\text { interviews }\end{array}$ \\
\hline $\begin{array}{l}\text { Strategy } \\
\text { development; clear } \\
\text { vision of where to } \\
\text { go with open data }\end{array}$ & $\begin{array}{l}9 \text { out of } 14 \\
\text { respondents } \\
\text { consider this } \\
\text { important }\end{array}$ & $\begin{array}{l}12 \text { out of } 15 \\
\text { respondents } \\
\text { consider this } \\
\text { important }\end{array}$ & $\begin{array}{l}\text { Top-down and bottom- } \\
\text { up developments are } \\
\text { important }\end{array}$ \\
\hline $\begin{array}{l}\text { Solid timeline for } \\
\text { introduction }\end{array}$ & $\begin{array}{l}7 \text { out of } 14 \\
\text { respondents } \\
\text { consider this } \\
\text { important }\end{array}$ & $\begin{array}{l}\text { Not included in } \\
\text { survey }\end{array}$ & $\begin{array}{l}\text { Not mentioned as } \\
\text { important by the } \\
\text { interviewees }\end{array}$ \\
\hline $\begin{array}{l}\text { Management } \\
\text { commitment }\end{array}$ & $\begin{array}{l}9 \text { out of } 14 \\
\text { respondents } \\
\text { consider this } \\
\text { important }\end{array}$ & $\begin{array}{l}\text { Not included in } \\
\text { survey }\end{array}$ & $\begin{array}{l}\text { The interviewees } \\
\text { emphasized the need for } \\
\text { multiple forms of } \\
\text { commitment, not just by } \\
\text { the management }\end{array}$ \\
\hline
\end{tabular}


Table 3. (Continued.)

\begin{tabular}{|c|c|c|c|}
\hline $\begin{array}{l}\text { Dividing roles and } \\
\text { responsibilities; } \\
\text { keeping track of } \\
\text { data }\end{array}$ & $\begin{array}{l}10 \text { out of } 14 \\
\text { respondents } \\
\text { consider this } \\
\text { important }\end{array}$ & $\begin{array}{l}10 \text { out of } 15 \\
\text { respondents } \\
\text { consider this } \\
\text { important }\end{array}$ & $\begin{array}{l}\text { This was considered } \\
\text { very important in order } \\
\text { not to risk damage to } \\
\text { the reputation of the } \\
\text { organization }\end{array}$ \\
\hline $\begin{array}{l}\text { Partnerships with } \\
\text { third parties }\end{array}$ & $\begin{array}{l}9 \text { out of } 14 \\
\text { respondents } \\
\text { consider this } \\
\text { important }\end{array}$ & $\begin{array}{l}13 \text { out } 15 \\
\text { respondents } \\
\text { consider this } \\
\text { important }\end{array}$ & $\begin{array}{l}\text { Considered difficult, } \\
\text { many questions arose } \\
\text { on how to connect with } \\
\text { potential re-users of the } \\
\text { data }\end{array}$ \\
\hline Business models & $\begin{array}{l}\text { Not included in } \\
\text { survey }\end{array}$ & $\begin{array}{l}10 \text { out of } 15 \\
\text { respondents } \\
\text { consider this } \\
\text { important }\end{array}$ & $\begin{array}{l}\text { Interviewees indicated } \\
\text { that they find it hard to } \\
\text { come up with good } \\
\text { business models for } \\
\text { open data }\end{array}$ \\
\hline $\begin{array}{l}\text { Embedding open } \\
\text { data in } \\
\text { organizational } \\
\text { processes }\end{array}$ & $\begin{array}{l}\text { Not included in } \\
\text { survey }\end{array}$ & $\begin{array}{l}8 \text { out of } 15 \\
\text { respondents } \\
\text { consider this } \\
\text { important }\end{array}$ & $\begin{array}{l}\text { Considered very } \\
\text { important, both top- } \\
\text { down and bottom-up }\end{array}$ \\
\hline $\begin{array}{l}\text { Standardization and } \\
\text { data quality }\end{array}$ & $\begin{array}{l}8 \text { out of } 14 \\
\text { respondents } \\
\text { consider this } \\
\text { important }\end{array}$ & $\begin{array}{l}13 \text { out of } 15 \\
\text { respondents } \\
\text { consider this } \\
\text { important }\end{array}$ & \\
\hline Metadata & $\begin{array}{l}\text { Not included in } \\
\text { survey }\end{array}$ & $\begin{array}{l}9 \text { out of } 15 \\
\text { respondents } \\
\text { consider this } \\
\text { important }\end{array}$ & \\
\hline $\begin{array}{l}\text { Opening } \\
\text { anonymized data } \\
\text { only }\end{array}$ & $\begin{array}{l}\text { Not included in } \\
\text { survey }\end{array}$ & $\begin{array}{l}\text { All respondents } \\
\text { consider this } \\
\text { important }\end{array}$ & \\
\hline $\begin{array}{l}\text { Creating a data } \\
\text { portal }\end{array}$ & $\begin{array}{l}\text { Not included in } \\
\text { survey }\end{array}$ & $\begin{array}{l}14 \text { out } 15 \\
\text { respondents } \\
\text { consider this } \\
\text { important }\end{array}$ & Considered important \\
\hline Pilot projects & $\begin{array}{l}10 \text { out of } 14 \\
\text { respondents } \\
\text { consider this } \\
\text { important }\end{array}$ & $\begin{array}{l}\text { Not included in } \\
\text { survey }\end{array}$ & $\begin{array}{l}\text { The pilot that was } \\
\text { undertaken was } \\
\text { considered very useful } \\
\text { to gain understanding in } \\
\text { how to open up data }\end{array}$ \\
\hline
\end{tabular}

\subsection{Barriers to Opening Data}

Questions on the barriers to opening data were asked in both surveys and during the interviews. Hence, we asked the respondents and interviewees to indicate which barriers are most important in each phase. Using a five-point scale (ranging from very important to very unimportant) we asked the respondents to indicate how they value the barriers. We changed the second survey based on the findings from the first survey. The main changes were the exclusion of security risks and the inclusion of business-related barriers. The results can be found in table 4 . 
Table 4. Enablers of open data in the RTO

\begin{tabular}{|c|c|c|c|}
\hline $\begin{array}{l}\text { Barriers to } \\
\text { opening data }\end{array}$ & $\begin{array}{l}\text { Preparation phase } \\
\text { survey }\end{array}$ & $\begin{array}{l}\text { Publication phase } \\
\text { survey }\end{array}$ & $\begin{array}{l}\text { Evaluation phase } \\
\text { interviews }\end{array}$ \\
\hline Security risks & $\begin{array}{l}9 \text { out of } 14 \\
\text { respondents } \\
\text { consider this } \\
\text { important }\end{array}$ & $\begin{array}{l}\text { Not included in } \\
\text { survey }\end{array}$ & $\begin{array}{l}\text { Due to a lack of } \\
\text { experience with open } \\
\text { data, the interviewees } \\
\text { are uncertain about the }\end{array}$ \\
\hline Privacy risks & $\begin{array}{l}6 \text { out of } 14 \\
\text { respondents } \\
\text { consider this } \\
\text { important }\end{array}$ & $\begin{array}{l}11 \text { out } 15 \\
\text { respondents consider } \\
\text { this important }\end{array}$ & $\begin{array}{l}\text { optimal degree of } \\
\text { openness, taking into } \\
\text { account privacy and } \\
\text { security }\end{array}$ \\
\hline $\begin{array}{l}\text { Lack of interest } \\
\text { by third parties }\end{array}$ & $\begin{array}{l}3 \text { out of } 14 \\
\text { respondents } \\
\text { consider this } \\
\text { important }\end{array}$ & $\begin{array}{l}7 \text { out } 15 \text { respondents } \\
\text { consider this } \\
\text { important }\end{array}$ & $\begin{array}{l}\text { Respondents at the RTO } \\
\text { stated that problems in } \\
\text { the communication } \\
\text { between the data-owner }\end{array}$ \\
\hline $\begin{array}{l}\text { Lack of a } \\
\text { business case for } \\
\text { open data }\end{array}$ & $\begin{array}{l}\text { Not included in } \\
\text { survey }\end{array}$ & $\begin{array}{l}9 \text { out } 15 \text { respondents } \\
\text { consider this } \\
\text { important }\end{array}$ & $\begin{array}{l}\text { and potential re-users } \\
\text { was an important } \\
\text { challenge }\end{array}$ \\
\hline $\begin{array}{l}\text { Reputation } \\
\text { damage to the } \\
\text { organization as a } \\
\text { result of low data } \\
\text { quality }\end{array}$ & $\begin{array}{l}10 \text { out of } 14 \\
\text { respondents } \\
\text { consider this } \\
\text { important }\end{array}$ & $\begin{array}{l}9 \text { out } 15 \text { respondents } \\
\text { consider this } \\
\text { important }\end{array}$ & \\
\hline $\begin{array}{l}\text { Reputation } \\
\text { damage to the } \\
\text { organization as a } \\
\text { result of re-use of } \\
\text { data }\end{array}$ & $\begin{array}{l}8 \text { out of } 14 \\
\text { respondents } \\
\text { consider this } \\
\text { important }\end{array}$ & $\begin{array}{l}11 \text { out } 15 \\
\text { respondents consider } \\
\text { this important }\end{array}$ & \\
\hline $\begin{array}{l}\text { Embedding open } \\
\text { data in the } \\
\text { organizational } \\
\text { strategies }\end{array}$ & $\begin{array}{l}5 \text { out of } 14 \\
\text { respondents } \\
\text { consider this } \\
\text { important }\end{array}$ & $\begin{array}{l}6 \text { out } 15 \text { respondents } \\
\text { consider this } \\
\text { important }\end{array}$ & $\begin{array}{l}\text { Respondents indicated } \\
\text { that translating open } \\
\text { data into the existing } \\
\text { organizational } \\
\text { strategies, e.g. on } \\
\text { innovation, and } \\
\text { processes is an } \\
\text { important barrier too }\end{array}$ \\
\hline
\end{tabular}

\section{$5 \quad$ Findings and Discussion}

In all three investigations, being a semi-public organization was seen as the main driver for having an open data strategy in place. In other words: open data was considered mostly from the viewpoint of transparency and accountability in the RTO. The second most important driving force for opening up data was the business value it could generate for the organization, either by developing business models for open data, or by using open data as a sales instrument. However, as the director of research stated, there may be a tension between the transparency and the commercial objective of the organization: "Our role in the world of open data is quite interesting. We want transparency, we want to stimulate re-use of our data and at the same time, we have to 
make money. In a way, this makes open data even more challenging for us than for public organisations". The third driver that was found important was enabling re-use by third parties. The strategist: "The public deserves an optimal return on investment in data we collect with public funding. We collected the data with a certain objective, but it can be useful for many other objectives we cannot even think of". This shows, firstly, that semi-public organizations often need to balance more strategies regarding open data than government organizations. Further research on the drivers of open data may focus on open data business models and how these models balance commercial and social goals $[25,26,27]$.

The first survey shows the importance for organizational enablers, such as undertaking pilot projects, developing a strategy for open data, management commitment, and clearly dividing roles and responsibilities in order to control the access to the data as well as the data quality. These were not mentioned in the literature and are thus added to the refined overview of drivers, enablers and barriers in table 5. In the second survey, factors related to the re-use of data were found especially important, such as privacy, standardization and publishing metadata, as well as connecting with re-users of data through setting up a data portal and partnerships with third parties. Especially factors related to building partnerships with end were not found in literature and therefore added to table 5. It thus appears that throughout the process of opening data, attention shifted from organizational issues to issues related to re-use. The interviewees corroborate this shift in their discussion on how to ensure the re-use of data. They found that randomly uploading data does not automatically lead to re-use. Instead, they consider the development of open data communities useful for stimulating re-use of data. The second finding is thus that throughout the process of open data, focus shifts from the internal organization to external users of data.

Also the importance attached to the barriers shifted between the first and the second survey. In the preparation phase barriers that were found most important were low data quality and the security risks of opening up data, for example the risk of data leaks, while the lack of interest from third parties, such as open data re-users was considered the least important challenge. After publication, security risks were replaced by privacy risks (and related reputation damage) as an important barrier to opening data. The runner-up barrier was the uncertainty of how open data would generate future revenue (added to table 5, as it was not found in literature). The interviewees still had doubts about how to balance privacy and security risks with the requirements of opening up data by the central government. A data owner: "It was difficult to decide which data to open, and on what level, because we also have to comply with the data protection act". The third finding is thus that throughout the process the more technically oriented barriers became less important as they were addressed, while factors regarding the impact of open data during re-use became more important. Still, the interviewees also maintained that a major challenge was to mobilize organizational support for an organization-wide open data strategy, and embed the open data strategy in the current data management processes (added to table 5). The director of research: "We need top-down as well as bottom-up support for open data". 
Table 5. Refined overview of organizational drivers, enablers and barriers to open data

\begin{tabular}{|c|c|c|c|}
\hline & Drivers & Enablers & Barriers \\
\hline $\begin{array}{l}\text { Information } \\
\text { technology }\end{array}$ & $\begin{array}{l}\text { Linked data } \\
{[4,12,13]}\end{array}$ & $\begin{array}{l}\text { Usefulness of the } \\
\text { databases }[4,10] ; \\
\text { Findability of the } \\
\text { data (technically as } \\
\text { well as through } \\
\text { advertisements) }\end{array}$ & $\begin{array}{l}\text { Poor data structures } \\
{[4,22] ; \text { Legacy }} \\
\text { systems }[4,22] ; \\
\text { Fragmented } \\
\text { databases }[4,22] ; \\
\text { Limited data quality } \\
{[4,6] ; \text { Lack of }} \\
\text { standardization }[4,6]\end{array}$ \\
\hline $\begin{array}{l}\text { Organizational and } \\
\text { managerial }\end{array}$ & $\begin{array}{l}\text { Efficiency and } \\
\text { budget cuts }[4,6,14]\end{array}$ & $\begin{array}{l}\text { Data stewardship } \\
{[4,10] ; \text { Clear }} \\
\text { implementation } \\
\text { strategy }\end{array}$ & $\begin{array}{l}\text { Complexity of the } \\
\text { changes to be made } \\
{[4,5] ; \text { Lack of }} \\
\text { business case for } \\
\text { generating revenue } \\
\text { from re-use; } \\
\text { embedding open data } \\
\text { in the strategy and } \\
\text { work processes }\end{array}$ \\
\hline $\begin{array}{l}\text { Legal and } \\
\text { regulatory }\end{array}$ & $\begin{array}{l}\text { PSI directive [9]; } \\
\text { Law enforcement } \\
\text { [6] }\end{array}$ & & $\begin{array}{l}\text { Privacy and data } \\
\text { protection }[4,6] ; \\
\text { national security }[4,6]\end{array}$ \\
\hline $\begin{array}{l}\text { Institutional and } \\
\text { environmental }\end{array}$ & $\begin{array}{l}\text { Transparency and } \\
\text { accountability } \\
{[2,4,14] \text {; Enabling }} \\
\text { re-use }[3,4,11,17]\end{array}$ & $\begin{array}{l}\text { Political leadership } \\
{[6] ; \text { Value for users }} \\
{[4,11]}\end{array}$ & $\begin{array}{l}\text { Closed culture of } \\
\text { government [6]; Lack } \\
\text { of support of user } \\
\text { feedback [4] }\end{array}$ \\
\hline
\end{tabular}

By looking at the process of opening up data in a semi-public organization, we found that during the process attention shifted from organizational concerns such as ensuring publication to concerns regarding re-use of the data and forging partnerships to with end users. While many government organizations regard opening up their data mainly as a technical process, this study finds that organizational aspects, both within the organization and with third parties re-using the data are found more important for realizing open data. The case study demonstrates that open data is an opening move for a more fundamental strategic process, in which multiple barriers (such as ensuring security, privacy and re-use) need to be dealt with. Based on this case study of the RTO we thus find that open data needs to be properly embedded both in the business proposition of organizations, as well as in the technology. This study thus corroborates findings that open data requires transformational changes to the organization of (semi-)public agencies [5].

The survey results also reflect the tension that is felt between the different drivers of open data: between those that reflect the public function of the organization and the commercial function of the organization. At different times, different enablers and barriers become more or less important. This may be an indication that this paradox is false: openness as a strategy can shift the commercial value of these data to intelligent services based on the data, but perhaps not simultaneously. Semi-public organizations require open, networked forms of innovation that, for example, change the way they interact within a networks of stakeholders [5]. Further research may look into how these different objectives can be achieved. One way of investigating this matter is by 
applying recent insights on institutional complexity and how organizations deal with competing logics triggered by information technologies [28,29], to better understand the organizational difficulties of opening up data.

\section{Conclusion}

This paper investigated the process of opening up data in a semi-public organization. Semi-public organizations differ in their objectives for opening up their data from public organizations. While government organizations mainly pursue open data because they aim to be transparent and accountable as well as enabling re-use of their data for economic purposes, semi-public organizations also aim to use open data to enhance their own strategic position and become more efficient and generate new income. Based on the case study of an RTO in the Netherlands, we found that while the drivers for open data remain the same throughout the process, the enablers and barriers shift. While internally focused, organizational factors were the main focus at the beginning of the process, attention shifted gradually to externally oriented factors, such as stimulating re-use and forging strategic partnerships with end users. Furthermore, we found that especially semi-public organizations have to deal with a variety of drivers for open data, based on their public and commercial goals, that they need to balance. Further research should thus focus on how to develop well-balanced open data business models, foster re-use and build strategic partnerships with end users around datasets as well. Furthermore, scholars can focus on how organizations can deal with these competing logics and with how organizations could align open data with their general strategy as well as their information technology.

\section{References}

1. McDermott, P.: Building open government. Government Information Quarterly 27, 401-413 (2010)

2. Jaeger, P.T., Bertot, J.C.: Transparency and technological change: Ensuring equal and sustained public access to government information. Government Information Quarterly 27(4), 371-376 (2010)

3. Harrison, T.M., Pardo, T.A., Cook, M.: Creating Open Government Ecosystems: A Research and Development Agenda. Future Internet 4(4), 900-928 (2012)

4. Janssen, M., Charalabidis, Y., Zuiderwijk, A.: Benefits, Adoption Barriers and Myths of Open Data and Open Government. Information Systems Management 29(4), 258-268 (2012)

5. Janssen, M., Zuiderwijk, A.: Open data and transformational government. In: tGov Conference, May 8-9. Brunel University, United Kingdom (2012)

6. Huijboom, N., van den Broek, T.: Open data: an international comparison of strategies. European Journal of ePractice 12(1) (2011)

7. Alani, H., Dupplaw, D., Sheridan, J., O'Hara, K., Darlington, J., Shadbolt, N.R., Tullo, C.: Unlocking the potential of public sector information with Semantic Web technology. In: Aberer, K., et al. (eds.) ASWC 2007 and ISWC 2007. LNCS, vol. 4825, pp. 708-721. Springer, Heidelberg (2007)

8. Bizer, C.: The emerging Web of linked data. IEEE Intelligent Systems 24(5), 87-92 (2009) 
9. Dawes, S.S.: Stewardship and usefulness: Policy principles for information-based transparency. Government Information Quarterly 27(4), 377-383 (2010)

10. Kalampokis, E., Tambouris, E., Tarabanis, K.: A classification scheme for open government data: towards linking decentralised data. International Journal of Web Engineering and Technology 6(3), 266-285 (2011)

11. European Commission: Open data, An engine for innovation, growth and transparent governance, $\operatorname{COM}(2011) 882$ final, Brussels (December 12, 2011)

12. Bizer, C., Heath, T., Berners-Lee, T.: Linked data-the story so far. International Journal on Semantic Web and Information Systems 5(3), 1-22 (2009)

13. Hausenblas, M.: Exploiting linked data to build web applications. IEEE Internet Computing 13(4), 68-73 (2009)

14. Hyland, B.: Preparing for a linked data enterprise. Linking Enterprise Data, 51-64 (2010)

15. Janssen, K.: The influence of the PSI directive on open government data: An overview of recent developments. Government Information Quarterly 28(4), 446-456 (2011)

16. Horsley, J.P.: Introduction on open government information implementation. Government Information Quarterly 23(1), 5-10 (2006)

17. Robinson, D., Yu, H., Zeller, W., Felten, E.: Government data and the invisible hand. Yale Journal of Law \& Technology 11 (2009)

18. Gil-Garcia, J.R., Chengalur-Smith, I., Duchessi, P.: Collaboratieve e-government: impediments and benefits of information-sharing in the public sector. European Journal of Information Systems 16, 121-133 (2007)

19. Ebrahim, Z., Irani, Z.: E-government adoption: architecture and barriers'. Business Process Management Journal 11(5), 589-611 (2005)

20. van Veenstra, A.F., Klievink, B., Janssen, M.: Barriers and impediments to transformational government: insights from literature and practice. Electronic Government: An International Journal 8(2-3), 226-241 (2011)

21. Gil-Garcia, J.R., Pardo, T.A.: E-government success factors: Mapping practical tools to theoretical foundations. Government Information Quarterly 22(2), 187-216 (2005)

22. Alani, H., Dupplaw, D., Sheridan, J., O’Hara, K., Darlington, J., Shadbolt, N.R., Tullo, C.: Unlocking the potential of public sector information with Semantic Web technology. In: Aberer, K., et al. (eds.) ASWC 2007 and ISWC 2007. LNCS, vol. 4825, pp. 708-721. Springer, Heidelberg (2007)

23. Klein, H.K., Myers, M.D.: A Set of Principles for Conducting and Evaluating Interpretive Field Studies in Information Systems. MIS Quarterly 23(1), 67-93 (1999)

24. Mingers, J.: Combining IS research methods: Towards a pluralist methodology. Information Systems Research 12(3), 240-259 (2001)

25. Vafopoulos, M.: A Framework for Linked Data Business Models. In: The 15th Panhellenic Conference on Informatics, Kastoria, Greece, September 30-October 2 (2011)

26. Ferro, O., Osella, M.: Business Models for PSI Re-Use: A Multidimensional Framework. In: The European Commission Workshop "Using Open Data: Policy Modeling, Citizen Empowerment, Data Journalism", Brussels, Belgium, June 19-20 (2012)

27. Deloitte: Pricing Of Public Sector Information Study (POPSIS). Report commissioned by the European Commission, DG CONNECT (October 2011)

28. Greenwood, R., Raynard, M., Kodeih, F., Micelotta, E.R., Lounsbury, M.: Institutional complexity and organizational responses. The Academy of Management Annals 5(1), 317-371 (2011)

29. Robey, D., Boudreau, M.C.: Accounting for the contradictory organizational consequences of information technology: Theoretical directions and methodological implications. Information systems research 10(2), 167-185 (1999) 